\title{
A new coral with simplified morphology from the oldest known Hettangian (Early Jurassic) reef in southern France
}

\author{
Mélanie Gretz, Bernard Lathuilière, and Rossana Martini \\ Acta Palaeontologica Polonica 60 (2), 2015: 277-286 doi:http://dx.doi.org/10.4202/app.00012.2013
}

The family Zardinophyllidae (Pachythecaliina) represents one of the most enigmatic coral groups known from the beginning of Mesozoic record of stony corals. They share some features with Paleozoic rugosans (overall architecture of the corallite) but also modern-day scleractinians (aragonite mineralogy). Fossil record of zardinophyllids was up to now restricted to the Triassic. Here we describe a new coral genus Cryptosepta collected in the oldest known Jurassic (Hettangian) reef in the Ardèche department in southern France. Cryptosepta gen. nov. has poorly developed (cryptic) septa, which is a peculiarity that extends the boundaries used to distinguish post-Palaeozoic corals and an oversimplification that could support reinitialisation of the evolutionary clock during extinction events or that support an adaptation to specific environmental conditions. Occurrence of Cryptosepta gen. nov. in Jurassic suggests zardinophyllid survival through the Triassic-Jurassic boundary, and may represent (possibly with Sinemurian genus Pachysmilia) a missing link to Amphiastreidae.

Key words: Anthozoa, Pachythecaliina, T-J boundary crisis, survival, evolution, Jurassic, Hettangian, France, Ardèche.

Mélanie Gretz [melaniegretz@ hotmail.com] and Rossana Martini [Rossana.Martini@unige.ch ], Department of Earth Sciences, University of Geneva, 13 rue des Maraîchers, 1205 Geneva, Switzerland; Bernard Lathuilière [bernard.lathuiliere@univ-lorraine.fr] Université de Lorraine G2R, UMR 7566, Vandoeuvre-lès-Nancy, BP 239, F-54506, France; CNRS G2R, UMR 7566, Vandoeuvre-lès-Nancy, BP 239, F-54506, France.

This is an open-access article distributed under the terms of the Creative Commons Attribution License (for details please see creativecommons.org), which permits unrestricted use, distribution, and reproduction in any medium, provided the original author and source are credited. 
Fof 